\title{
Psychological and socio-demographic correlates of women's decisions to give birth at home
}

\section{BACKGROUND}

Some women decide to give birth at home. They treat their home as a safe place to do so, are against medicalization of natural labour or value activity and autonomy during labour. They are also characterized by good knowledge of their own bodies and about labour in general (including labour at home).

Psychological studies have revealed a correlation between labour (including the derived satisfaction) and the levels of dispositional optimism, perception of efficacy, and coping with pain. Analysis of the available demographic data shows that the decision to give birth at home is correlated with a certain socio-demographic profile of women.

\section{PARTICIPANTS AND PROCEDURES}

One hundred thirty five mothers took part in the study. Among them 72 had given birth at home and 63 in a hospital. The following were assumed as important psychological determinants: dispositional optimism, sense of self-efficacy, strategies for coping with pain and their effectiveness. The LOT-R Test, GSES Scale, CSQ Questionnaire as well as a demographic questionnaire were used in the study.

\section{RESULTS}

Women who gave birth at home were characterised by significantly higher levels of optimism and sense of self-effi- cacy in comparison with the other women. Women giving birth at home reinterpreted the sensations of pain more frequently than the others, who were more likely to catastrophise and pray/hope. The level of conviction about having control over pain was much higher in the experimental group. The relationship between choice of place to give birth and the level of education, marital status, area of residence as well as age is weak. Correlations between the place of birth and income, number of children as well as membership of religious communities are moderate and statistically significant.

\section{CONCLUSIONS}

It is important to see and meet the different expectations of the two distinct groups of women. Today's phenomenon of homebirth requires systematic interdisciplinary research. The system of obstetric care should get ready for the ongoing social changes. It is also necessary to systematically collect socio-demographic data of women giving birth at home. Further research, as well as the use of current results in the process of selecting women to give birth at home, is suggested.

\section{KEY WORDS}

birth at home; dispositional optimism; perception of selfefficacy; coping strategies for pain

organizations - 1: Department of Social Medicine, Collegium Medicum in Bydgoszcz, Nicolaus Copernicus University in Torun, Poland · 2: Department of Clinical Psychology, Collegium Medicum in Bydgoszcz, Nicolaus Copernicus University in Torun, Poland · 3: Institute of Psychology, Kazimierz Wielki University in Bydgoszcz, Poland AUthors' CONTRIBUtion - A: Study design - B: Data collection - C: Statistical analysis - D: Data interpretation E: Manuscript preparation · F: Literature search · G: Funds collection

CORResponding AUthor - Urszula Domańska, Collegium Medicum in Bydgoszcz, Nicolaus Copernicus University in Torun, 20 Świętojańska Str., 85-077 Bydgoszcz, Poland, e-mail: urszuladomanska@wp.pl

TO Cite this ARTICle - Domańska, U., Ossowski, R., \& Ciżkowicz, B. (2014). Psychological and socio-demographic correlates of women's decisions to give birth at home. Health Psychology Report, 2(3), 197-207. DOI: 10.5114/hpr.2014.45156 


\section{BACKGROUND}

In Poland, planned home birth is treated as an incidental phenomenon as it represents less than one percent of all births. Therefore there is no scientific research into the issue.

However, interdisciplinary research (both qualitative and quantitative), independent of the percentage of home births, and despite the varying health care systems, takes place in the USA, Canada, Australia, UK, New Zealand, Scandinavia, Belgium, and the Netherlands (e.g. Abel \& Kearns, 1991; Boucher, Benett, McFarlin, \& Freeze, 2009). Studies from these countries suggest that the interest in non-institutional birth in recent years has been growing (McDorman, Declerq, \& Menacker, 2011; McDorman, Declerq, \& Mathews, 2011).

The European Court of Human Rights in Strasbourg confirmed the right of a woman to make personal decisions about parenthood, including the right to choose the place of birth. This includes the obligation of the State to create a legal order, under which giving birth at home is legal and it does not expose the participants to any direct or indirect sanctions (European Court of Human Rights, 2010).

The modern planned home birth is not a replica of home birth as it was in the past. Both the midwives and women involved in the procedure use current medical knowledge, as well as physical and laboratory examinations, ultrasonography or fetal electronic monitoring in the prenatal period. They undergo tests assessing the eligibility of a woman for home birth. During the labour the midwife is equipped with pharmaceuticals and life-saving equipment. The health system recognises home birth as the lowest level of referral of obstetric care and ensures collaboration with a hospital in case of the necessity of transferring the woman in labour to a hospital (Kitzinger, 1995; Lindgren, Hildingsson, Christensson, \& Radestad, 2008; Sagov, Feinbloom, Spindel, \& Brodsky, 1984; Wegers, van der Zee, \& Keirse, 1998).

The available research portrays women who give birth at home as those who treat their home as a safe place to do it, are against medicalization of natural labour or value activity and autonomy during labour. They are also characterized by a good knowledge of their own bodies and about labour in general, which includes labour at home (Chołuj, 2008; Janiuk \& Lichtenberg-Kokoszka, 2010; Sagov et al., 1984).

It is important to stress that giving birth at home is not a solution for every woman. It requires a reliable classification according to the health, psychological, and socio-demographic situation of women. It is not, and should not, be available to women who, due to certain risk factors, need special inpatient perinatal care.

A full psychosocial profile of women giving birth at home is difficult to find in the literature. Knowl- edge about the medical and psychosocial factors that shape the decision to choose the home as the place to give birth and place of professional practice would undoubtedly help to qualify women to give birth at home.

The current article considers psychological characteristics such as dispositional optimism, sense of self-efficacy and perception of being able to control one's own pain, as well as sociodemographic data such as age, level of education, marital status, and number of children, income and membership of religious communities.

In the age of medicalization of obstetrics, the choice to give birth at home is a conscious decision made by a woman and her partner. The parents are aware that their choice is at odds with current cultural norms - it deviates from the standard solutions that are accepted by society and might evoke strong emotions in their social environment or among medical personnel (Hildingsson, Radestad, \& Lindgren, 2010).

The decision to give birth outside of a hospital is the result of interactions between many medical, emotional, social, spiritual and cultural factors (Bebelska \& Chazan, 2011).

The first group involves factors related to the health of mother and child. The rules for qualifying for non-hospital birth include absolute and relative indications that were developed and published by midwives specialising in homebirth (Dzierżak-Postek et al., 2010).

The socio-cultural factors at play in the process of making the choice were listed in the article by Dorota Kornas-Biela. The 'back to nature' trend and the environmental movement seem to be among the most important factors. For couples associated with "eco-parenting", and "conscious parenting from the moment of conception" trends, home might be the most natural place for the birth of their child.

The researcher also brings to attention the rarely stressed factor of having a small number of children and the consequences of that trend. The experience of giving birth is currently a rare phenomenon in the life of a woman, the memory of which will last for her whole life. This situation encourages parents to place particular emphasis on the best possible physical and psychosocial conditions of delivery, so that both the mother and the child feel comfortable, which reinforces efforts to preserve the woman's subjectivity during labour.

Today, women treat pregnancy and labour as an element of conscious self-negotiation and creation. For some women this means exercising the right to give birth without pain and seeking to receive anaesthesia during childbirth or give birth through caesarean section. Others want to exercise the right to choose the place to give birth and celebrate the natural birth at home. Another factor listed by the researcher is the increasing attention to improving 
the quality of life - a result of the humanistic trend in modern societies - which includes the quality of the process of birth (Kornas-Biela, 2011).

Ewa Janiuk highlights, the fact that the fear of hospital procedures as well as previous negative experience of hospital labour may be reasons to choose home as a place of birth. However, this choice should not rely solely on negative factors and in such cases other satisfactory solutions are sought for the woman (Janiuk, 2011).

An on-line study by Boucher et al. (2009) contributed to determining the frequency of reasons for the choice of home birth. According to the study, the most frequent reasons for the choice reported by the respondents were: safer, better birth (35\%), avoidance of unnecessary medical interventions (35\%), previous negative experience of giving birth at a hospital (35\%), the power to exercise control and comfort (35\%). These were followed by: privacy (28\%), reluctance towards hospital and doctors (28\%), trust in nature (25\%), a desire to do what is best for the baby (24\%), the possibility to choose a preferred caregiver/ midwife (23\%), a desire for a drug-free birth (20\%), family participation (19\%), a natural experience (17\%), psychological wellbeing (16\%) and other. History of fast birth was listed as the last reason (5\%).

Women seeking an alternative place of birth do not look for a specific environment in a physical sense, but rather a specific philosophy of natural birth together with caretakers who will enable it (Dahlen, Barclay, \& Homer, 2008; Lothian, 2010).

Research by Hazell analysed 300 home births between 1969 and 1973 in America. It revealed that the choice of home as a place to give birth was equally common in traditional American families as in subculture or counterculture groups (Sagov et al., 1984).

A study carried out in Washington between 1989 and 1996 suggests that the choice of home birth is more frequent among women who are married, have higher education, hold feminist views and are not occupationally active (Bebelska \& Chazan, 2011).

Another study from the USA (from 1990-2006) revealed that white women and women from outside of ethnic minorities decide to give birth at home more often. They are most frequently multiparous women, above the age of 35. During the planned home births they are most often assisted by midwives. When women of other ethnicities gave birth at home it was more frequently unplanned (McDorman et al., 2011; Boucher et al., 2009).

The number of women giving birth at home in the USA increased from $0.56 \%$ in 2004 to $0.72 \%$ in 2009 . Clear differences are visible in the number of home births depending on the area of residence. E.g. $0.20 \%$ of births in Louisiana and the State of Columbia are home births, whereas in Oregon and Montana the frequency is $2.00 \%$ and $2.60 \%$ respectively (Mac Dorman et al., 2011; Boucher et al., 2009). Individuals who decide to give birth at home represent various occupational groups, including medical professionals, and can be both wealthy and not wealthy (Sagov et al., 1984; Viisainen, 2000).

According to the research by Hazell (1969-1973), Sagov (1976-1980) and Viisainen (1995-1996), women who choose to give birth at home are also characterised by choosing a healthy lifestyle, are eco-friendly and live in harmony with nature. They value preventive functions of medicine and personal responsibility, and their romantic relationships are characterised by partnership. They value family and they perceive themselves and their decisions in the context of their consequences for the social environment (Sagov et al., 1986; Viisainen, 2000).

Research from Sweden shows that women giving birth at home are usually aged between 26 and 35 and characterised by secondary or high levels of education. They are usually in romantic relationships, and are frequently multiparous or planning to have more children (Hildingsson et al., 2010; de Jonge et al., 2009; Lindgren \& Erlandsson, 2010).

No research on the socio-demographic aspects of home birth has been carried out in Poland. Statistics offered by Stowarzyszenie Dobrze Urodzeni (Polish for: the Society of Well-Born) are the only available source of information. They gather data from midwives specialising in home birth affiliated with the society. According to the society's report, 110 women decided to give birth at home in 2011. They were most frequently aged between 26 and 30 or 31 and 36 , with higher education. Less frequently, they were women aged between 20 and 25, with secondary education. No women with primary or vocational education gave birth at home. There is no information about age in the case of 27 women, and about the level of education of 7 women. Twenty six women gave birth for the first time, 84 women were multiparous, and there is no information about the number of children for 4 women (Krauze, 2012).

Psychological factors are also important in the decision about the place to give birth. A body of psychological research stresses the significance of the quality of birth not only for the woman's self-esteem but also the proper development of the child (Kornas-Biela, 2011). The choice of home as the birthplace is correlated with three dimensions that are not available to the women in hospital conditions: control (over the act of birth), continuity and the familiarity of home (associated with the sense of safety) (Abel \& Kearns, 1991).

The interest in homebirth and the associated satisfaction with fulfilment of the expectations for the act (or lack thereof) can be explained within the general self-efficacy theory by Albert Bandura. The theory assumes that the perception of self-efficacy allows an individual to set ambitious goals and it aids the perseverance in pursuing them. It allows the individual
The decision to give birth at home 
Urszula Domańska, Roman Ossowski, Barbara Ciżkowicz to invest efforts in the pursuance, and to successfully cope with stress (Juczyński, 1998, 2000, 2001).

Research among pregnant women is concerned with e.g. the correlation between perception of selfefficacy and fear of labour (Beebe, Lee, Carrieri-Kohlman, \& Humphreys, 2007; Lowe, 2000). Lowe investigated 280 women in the third trimester of pregnancy, divided into those characterised by low and high levels of pre-labour anxiety. He noted that, in contrast to the women in the low anxiety group, women in the high anxiety group were characterised by low self-esteem, significantly higher levels of learned helplessness and lower sense of self-efficacy. Fears were associated mostly with the mental image of losing control over the course of labour, labour pain and the health of the child (Lowe, 2000).

The theory of Albert Bandura was also applied in studies about the duration of labour, pain, and the use of analgesics during labour (Callister, Vehvilainen-Julkunen, \& Lauri, 2001; Lowe, 1991; Manning \& Wright, 1983). Research by Manning and Wright confirmed the positive correlation between the sense of self-efficacy and the control over pain without the use of pharmaceuticals (Manning \& Wright, 1983). Lowe analysed the influence of the sense of self-efficacy on the perception of labour pain and highlighted the implications of those correlations for the perinatal care (Lowe, 1991). Similarly, the qualitative study by Callister and co-workers confirmed the correlation between high self-esteem and perception of labour pain. Women recalled the event of labour as a challenge and a stage in self-realization (Callister, Vehvilainen-Julkunen, \& Lauri, 2001).

Research carried out in 2004-2005 on a group of 560 Danish and Belgian women revealed a correlation between perception of high self-efficacy and high levels of satisfaction from giving birth (Christiaens \& Bracke, 2007).

The relation between the choice of mode of delivery and the perception of self-efficacy was also analysed among women whose first delivery was through caesarean section. Women who planned caesarean section as the method of delivery of their second child were characterised by a lower perception of self-efficacy (Dilks \& Beal, 1997).

All of these studies confirm that women with a higher sense of self-efficacy deal better with labour pain, are characterised by lower levels of pre-labour anxiety and are more satisfied with giving birth.

Research on labour pain that is not associated with Bandura's theory also shows that pain is not only a manifestation of a physiological process, but a result of biological, psychological and socio-cultural processes simultaneously taking place in woman in labour. Subject literature presents many issues concentrated around labour pain, such as understanding the nature of labour pain and its perception by women (Lowe, 1996; Witkiewicz, 2011), percep- tions of labour pain and the use of pharmaceuticals (Green, 1993), correlations between labour pain and support from the midwife as well as the continuity of care (Leap, Sandall, Buckland, \& Huber, 2010), and personal and cultural differences in the perception of labour pain (Budrowska, 2000; Callister, Kalaf, Semenic, Kartchner, \& Vehvilainen-Julkunen, 2003).

Similarly, the problem of anxiety associated with labour appears in the literature as an effect of a combination of socio-cultural and psychological factors (Domańska, 2012; Ponte, 2007; Rieger \& Dempsey, 2006).

Dispositional optimism is another personal resource that may explain the process of making decisions about home birth as well as the attitude during labour (Scheier \& Carver, 1985, 1992). It influences the ability to succeed in life and the resistance to stressful events (Juczyński, 2001; Poprawa, 1996). A tool to measure optimism was used in research about perinatal care. Optimism was juxtaposed with postpartum depression (Carver \& Gaines, 1987) or the condition of lasting stress experienced by women in high-risk pregnancies (Lobel, de Vincent, Kaminer, \& Meyer, 2000).

These studies confirm that optimism encourages positive strategies of problem solving, whereas pessimism leads to negative self-evaluation and negative evaluation of the situation as well as refraining from action.

High levels of optimism are also associated with another psychological characteristic of an individual, namely mental resilience. This quality allows pregnant women to seek successful strategies for coping with difficult situations associated with pregnancy and labour (Pawlicka, Chrzan-Dętkoś, \& Lutkiewicz, 2013).

Marina Sbisa stresses that the experience of labour is an important event in a woman's life - a woman may construct her own identity based on it. Women might have two alternative attitudes towards labour: trying to survive it (passive attitude) or to experience it (active). These polar attitudes are manifested in very distinct verbal accounts of the event. It is particularly visible in the choice of the form of verbs used in the accounts. The choice of verbs ranged from the use of passive forms of verbs (e.g. something was done to me) in the case of the survival strategy, to the use of agentive active forms (e.g. I suddenly opened up) (Budrowska, 2000).

Women who gave birth at home define labour as a process full of pain and power over which they have control through recognition of their own experiences, identifying their own needs as well as having a support system. Home birth is often described as an event in which the woman in labour maintains her subjectivity (Lindgren \& Erlandsson, 2010). In accounts of the experience, women tend to focus on self-determination, control and putting trust in instincts (Viisainen, 2001; Jouhki, 2011). 
They have a particular attitude towards labour pain. The literature review by Lally and co-workers brings attention to four key associated aspects: the level and type of pain, the issue of relief in suffering, women's participation in decision making and pain control. According to the authors, there is an expectation-reality gap with regards to the experience of pain as well as the associated planned relief/coping solutions (Lally, Murtagh, Macphail, \& Thomson, 2008).

Women who give birth at home are aware that they cannot receive analgesia at home. However, frequently they do not treat labour pain as a pathology, instead trying to interpret it as a physiological manifestation informing them about the processes occurring within the body during delivery. They use non-pharmaceutical methods of pain relief. This attitude is at odds with the typical approach in Western culture, where the elimination of labour pain is an end in itself (Kubicka-Kraszyńska, Otffinowska, \& Pietrusiewicz, 2006).

A number of studies suggest that satisfaction with labour does not arise from the elimination of pain (Kubicka-Kraszyńska et al., 2006). Instead, successful coping with pain using non-pharmaceutical methods leads to satisfaction and strengthens the sense of agency among women (Leap et al., 2010; Lindgren \& Erlandsson, 2010).

Perceiving home as a safe place can have a protective impact on woman in labour. Lack of hostile external stimuli, lack of stress, full intimacy, and lack of intervention stimulate the secretion of the hormone oxytocin, facilitate the release of endorphins, and protect women from experiencing uncontrolled pain (Kubicka-Kraszyńska et al., 2006). Women emphasize the importance of a peaceful atmosphere and the possibility of choosing forms of relaxation at home that are appropriate to the phase of delivery and their needs, all of which results in reducing the experience of pain (Lindgren \& Erlandsson, 2010).

Trust in the midwife and the sense of self-efficacy are useful for the control of pain (Callister et al., 2001; Juczyński, 2001). Evaluative support from the midwife, promoting the conviction that the woman is ready to confront the pain as well as the continuity of care (the same midwife during pregnancy and labour) can be similarly helpful.

The goal of empirical research presented in the current article was to analyse selected psychological and socio-demographical factors that are associated with the choice of home as the place of birth.

\section{PARTICIPANTS AND PROCEDURE}

One hundred thirty five mothers took part in the study. Seventy two women constituted the experimental group of women who planned to give birth at home. The remaining 63 women gave birth at a hospital and formed the control group. Planning and undergoing at least one delivery at home was the criterion for inclusion in the experimental group. The criterion for women in the control group was having had a healthy pregnancy and given a natural birth (both of which are the basis for qualifying women for home birth).

The selection of subjects was non-random. An available pool of subjects was used in order to achieve the broadest and most complete information about the investigated population. Women in the experimental group were recruited mostly through midwives specialising in homebirth, but when their number turned out to be too small, more women were contacted through a homebirth internet forum. Women received a link to an on-line survey ${ }^{1}$. The survey was available only through a secret link, and no more than one attempt was allowed from the same computer.

Women in the control group were recruited as volunteers from the hospital maternity ward in a region's capital city. Women in the experimental group were recruited from various regions of Poland, where one can practise homebirth.

The following factors were selected as important psychological indicators: dispositional optimism, sense of self-efficacy, strategies for coping with pain and the effectiveness of those strategies. The level of optimism was investigated using the Life Orientation Test (LOT-R), first developed by Michael F. Scheier and Charles S. Carver (1992) and revised in 1994 by Michael F. Scheier, Charles S. Carver and Michael W. Bridges. The Polish version of the test was prepared by Ryszard Poprawa and Zygfryd Juczyński (Juczyński, 2001). The tool measures the level of optimism that is an important personal resource for an individual, influences their physical state and wellbeing, and is responsible for their resistance to stressful life events. It consists of 10 items and the respondent gives answers on a 5-point scale (Juczyński, 2001).

This test was used to examine both pregnant women and midwives, as labour had been assessed as a stressful life event (SRRS Stress Scale by Holmes and Rahe). Optimism may influence both the decision about homebirth and the course of delivery.

The sense of self-efficacy was measured using the Generalized Self-Efficacy Scale (GSES). The scale was developed by Matthias Jerusalem and Ralf Schwarzer (1992 - German version; 1993 - English version) and it is related to the Self-Efficacy theory by Albert Bandura. It was adapted to Polish by Ralf Schwarzer, Matthias Jerusalem and Zygfryd Juczyński (Juczyński, 2001). The perception of self-efficacy guarantees setting progressively more ambitious goals in life and engagement in their pursuit. The scale consists of 10 items and a 4-point answering scale (Juczyński, 2001). It was used to investigate women giving birth at home as well as the midwives, as the perception of self-efficacy can be a factor influencing the decision to give birth at home.
The decision to give birth at home 
Urszula Domańska, Roman Ossowski, Barbara Ciżkowicz
Strategies of coping with pain were examined using the Coping Strategies Questionnaire (CSQ), constructed by A. C. Rosenstiel and F. J. Keefe (1983). The questionnaire comprises 42 items describing methods for coping with pain, and two questions that help to establish the respondent's skills of coping with pain. The answers are given on a 7-point Likert scale (Juczyński, 2001). The questionnaire is used to assess the respondent's strategies of coping with pain and the efficacy in implementing these strategies (Juczyński, 2001). The CSQ test was used in order to verify women's strategies of coping with labour pain.

A demographic questionnaire was used in order to gather the socio-demographic data about women from the experimental and control groups.

The study verified the following hypotheses:

1. Women choosing to give birth at home are characterized by higher levels of dispositional optimism than those who give birth at a hospital;

2. Women choosing to give birth at home are characterized by a higher sense of self-efficacy than those who give birth at a hospital;

3. Women choosing to give birth at home are characterised by a higher sense of control over pain (the ability to cope with or reduce pain) than those who give birth at a hospital. They cope with pain by reinterpreting pain and declaring the ability to cope with pain;

4. There is a correlation between the choice of place to give birth and demographic characteristics such as age, education, marital status, area of residence, income, children and membership of religious communities.

\section{RESULTS}

We analysed the correlations in the acquired empirical data. It is important to stress that statistical analysis was used in order to check if the observed relationships between variables and differences between parameters can be interpreted as random error, or are a consequence of systematically occurring relationships and differences. Because the study used the available pool of subjects (non-random selection) we cannot infer that the results are true for the population - such a generalisation would generate parameter estimation errors that are difficult to define. The distribution of the psychological variables was analysed in order to verify that it is characterized by normal distribution (Table 1).

The Shapiro-Wilk test allowed us to assume that variables such as diverting attention, praying, declaring the ability to cope and increased behavioural activity do not deviate significantly from the normal distribution $(p=.051)$.

The Shapiro-Wilk test suggested a significant ( $p=.051)$ deviation from the normal distribution of variables such as reinterpreting pain, catastrophisation and ignoring experiences. Despite that, the skewness and kurtosis analysis, taking to account the size of the sample and sensitivity of the tests of deviations from the normal distribution, allows the use of a parametric test.

Comparative analysis of means (Student $t$-test) was used in order to verify whether the choice of place to give birth (home/hospital) significantly differentiates the psychological variables. The results are presented in Table 2 .

Table 1

Distribution of psychological variables

\begin{tabular}{lcccc}
\hline \multicolumn{1}{c}{ Psychological variables } & Mean & SD & Skewness & Kurtosis \\
\hline Dispositional optimism (LOT-R) & 18.06 & 3.90 & -0.45 & -0.65 \\
Sense of self-efficacy (GSES) & 32.07 & 4.63 & -0.13 & -0.31 \\
CSQ & & & -0.53 \\
1. Diverting attention & 13.89 & 8.11 & 0.27 & 0.75 \\
2. Reinterpreting pain & 11.84 & 8.60 & 0.69 & -0.23 \\
3. Catastrophisation & 10.35 & 7.00 & 0.42 & -0.43 \\
4. Ignoring experience & 12.44 & 8.45 & 0.53 & -0.59 \\
5. Prayer/hoping & 17.14 & 7.50 & -0.31 & 0.28 \\
6. Declaration of coping & 19.87 & 7.03 & -0.10 & -0.56 \\
7. Increased behavioural activity & 14.98 & 7.73 & -0.05 & 0.69 \\
8. Pain control & 3.71 & 1.18 & -0.51 & 1.24 \\
9. Ability to reduce pain & 3.21 & 1.13 & -0.32 & \\
\hline
\end{tabular}


Results of Student t-test for independent groups

\begin{tabular}{|c|c|c|c|c|c|}
\hline Psychological variables & $\begin{array}{l}\text { Women who } \\
\text { gave birth at } \\
\text { a hospital, } \\
N=63(1)\end{array}$ & $\begin{array}{c}\text { Women who } \\
\text { gave birth at } \\
\text { home, } \\
N=72(2)\end{array}$ & Test result & $\begin{array}{l}S D \\
(1)\end{array}$ & $\begin{array}{l}S D \\
(2)\end{array}$ \\
\hline & $M$ & $M$ & $t$ & & \\
\hline Dispositional optimism - DOPT (LOT-R) & 16.20 & 19.70 & $-5.62^{* \star *}$ & 3.69 & 3.09 \\
\hline Sense of self-efficacy - SSE (GSES) & 30.30 & 33.60 & $-4.45^{\star \star \star}$ & 4.64 & 4.90 \\
\hline Diverting attention - DA (CSQ) & 14.00 & 13.70 & 0.17 & 8.45 & 7.86 \\
\hline Reinterpretation of pain - RIP (CSQ) & 9.90 & 13.60 & $-2.56^{* *}$ & 8.17 & 8.65 \\
\hline Catastrophising $-\mathrm{C} 0(\mathrm{CSQ})$ & 12.90 & 8.20 & $4.13^{* \star *}$ & 5.56 & 6.66 \\
\hline Ignoring experience - IE (CSQ) & 12.40 & 12.50 & -0.06 & 8.43 & 8.53 \\
\hline Praying/Hoping - $\mathrm{P}$ (CSQ) & 19.30 & 15.30 & $3.16^{* *}$ & 7.28 & 7.24 \\
\hline Declaration of coping - DC (CSQ) & 19.70 & 20.00 & -0.24 & 6.68 & 7.37 \\
\hline Increased behavioural activity - IBA (CSQ) & 15.10 & 14.90 & 0.19 & 8.14 & 7.40 \\
\hline Pain control - PC (CSQ) & 3.40 & 4.00 & $-3.48^{* * *}$ & 1.17 & 1.10 \\
\hline Ability to reduce pain - ARP (CSQ) & 3.20 & 3.20 & -0.16 & 1.98 & 1.25 \\
\hline
\end{tabular}

The decision to give birth at home
Women who chose to give birth at home were characterised by higher levels of dispositional optimism than women who gave birth at a hospital (results of the LOT-R test).

Women who chose to give birth at home were characterised by a higher sense of self-efficacy than women who gave birth at a hospital (results of the GSES test).

Analysis of the CSQ test revealed differences between women who gave birth at home and those who gave birth at hospital in three ways of coping with pain. Women who gave birth at home reinterpreted the experience of pain significantly more often, whereas the women giving birth at a hospital used methods of coping with pain categorized in the test as prayer/hoping or catastrophising significantly more often.

The perception of being able to reduce pain is similar in both groups. However, the perceived control over pain was significantly higher for the women giving birth at home (Figure 1).

A graph illustrating the psychological profiles of both groups is presented below (the symbols of variables used in the graph are explained in Table 2).

Our hypothesis assumed that a correlation exists between demographic features such as age, education, marital status, area of residence, income, children as well as being in a religious community and the choice of place to give birth.

Cramer's V coefficient was used to verify the correlations between the place of birth and the demographic variables (age, education, area of residence, income). Yule $\varphi$ coefficient was used in the case of dichotomous variables such as the number of children ( 1 - one child; 2 - more than one child), being in a religious community $(1-$ yes; $2-$ no) and marital status ( 1 - married; 2 - single) (Table 3 ).

The calculated strength of the relationship between the place of giving birth and the level of education, marital status, area of residence and age was weak. The relationships between the place of birth and income, number of children as well as being in a religious community were moderate, and the test of independence allowed us to confirm their statistical significance.

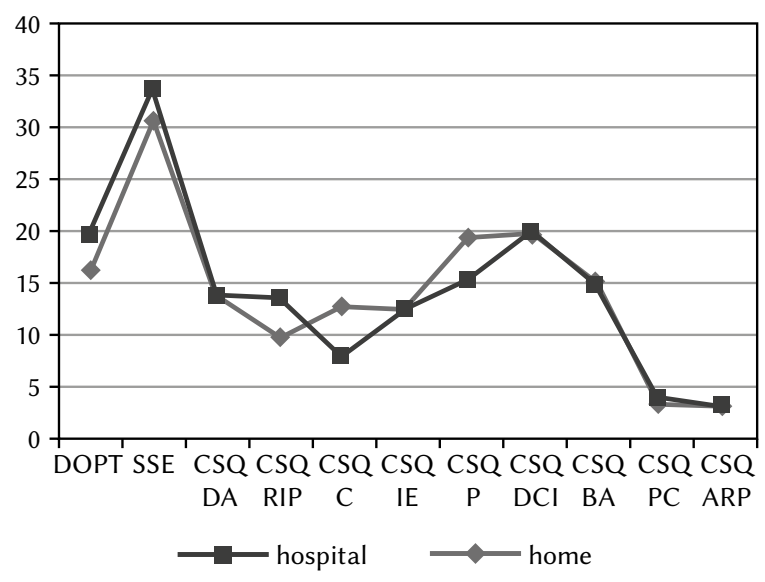

Figure 1. Psychological profile of women who chose to give birth at home and those who gave birth at a hospital (compare with Table 2). 
Table 3

Values of Cramer's $V$ and Yule $\varphi$ coefficients

Urszula Domańska,

Roman Ossowski, Barbara Ciżkowicz

\begin{tabular}{lcccc}
\hline \multicolumn{1}{c}{ Variables } & Cramer's V & $\chi^{2}$ & $d f$ & $p$ \\
\hline Age & 0.08 & 0.84 & 3 & .841 \\
Education & 0.28 & 10.71 & 2 & .004 \\
Area of residence & 0.13 & 2.31 & 2 & .316 \\
Income & 0.34 & 15.84 & 2 & $<.001$ \\
\hline \multicolumn{1}{c}{ Variables } & Yule $\varphi$ & $\chi^{2}$ & $d f$ & $p$ \\
\hline Being in a religious community & 0.35 & 16.38 & 1 & $<.001$ \\
Number of children & 0.33 & 14.59 & 1 & $<.001$ \\
Marital status & 0.16 & 3.34 & 2 & .188 \\
\hline
\end{tabular}

Discriminant analysis was used to determine which psychological and demographic variables can significantly differentiate women in terms of the chosen place to give birth. Psychological variables whose means significantly differed depending on the place of birth as well as the demographic variables that were moderately $(r>30)$ correlated with the place of birth were taken into account in the analysis. The decision to limit the number of variables in the analysis was based on the fact that the size of the sample was too small to simultaneously analyse all the variables in the research model.

Results of forward stepwise analysis are presented in Table 4.

As a result, one out of nine predictors included in the analysis was removed: control of pain (CSQ).

Among the remaining variables, the levels of optimism, number of children, and being in a religious community turned out to be the most important factors in predicting the choice of place to give birth. The other variables were insignificant, though they improved the fit of the model. Non-orthogonality of those variables was the likely reason for the weakening of the predictive power, which was confirmed by the bivariate correlations between the predictors.

The eigenvalue for a canonical root was 1.25 , and the $\chi^{2}$ test led to the conclusion that this result was highly significant $(p<.001)$.

\section{DISCUSSION}

The hypothesis that women who choose to give birth at home are characterised by higher levels of dispositional optimism and higher sense of self-efficacy than women who give birth at a hospital was confirmed.

The hypothesis that women giving birth at home are characterised by a higher sense of control over pain (the ability to cope with it and reduce it) than women giving birth at a hospital was partially confirmed. Women who gave birth at home were characterised by a higher sense of control over pain, but it was not confirmed that they had a significantly higher ability to reduce it. They used the coping strategy of reinterpretation of pain to a significant degree. No

Table 4

Discriminant analysis for place of birth

\begin{tabular}{lcccc}
\hline \multicolumn{1}{c}{ Psychological and demographic variables } & $\begin{array}{c}\text { Wilks' } \\
\text { lambda }\end{array}$ & $\begin{array}{c}\text { Partial } \\
\text { lambda }\end{array}$ & $\begin{array}{c}F \text { to enter } \\
(1,126)\end{array}$ & $p$ \\
\hline Dispositional optimism (LOT-R) & 0.57 & 0.96 & 4.71 & .032 \\
Number of children & 0.62 & 0.88 & 17.37 & $<.001$ \\
Community & 0.62 & 0.88 & 17.43 & $<.001$ \\
Sense of self-efficacy (GSES) & 0.56 & 0.98 & 3.01 & .085 \\
Catastrophising (CSQ) & 0.55 & 0.99 & 1.84 & .178 \\
Income & 0.56 & 0.98 & 3.08 & .082 \\
Declaration of coping (CSQ) & 0.56 & 0.97 & 3.58 & .061 \\
Prayer/Hoping (CSQ) & 0.56 & 0.98 & 2.87 & .093 \\
\hline
\end{tabular}


significance was observed for the strategy of declaring the ability to cope.

The hypothesis assuming a correlation between the demographic variables and the choice of place to give birth was also partially confirmed. It proved to be true for variables such as income, number of children, and being in a religious community. It was rejected for variables such as education level, marital status, area of residence and age.

The levels of optimism, number of children and being in a religious community turned out to be the most important in differentiation of women according to the place of giving birth. The remaining variables were insignificant, though they improved the fit of the model.

Our research showed that the group of women giving birth at home was characterized by a set of psychological and socio-demographic features that should be taken into account when selecting women to give homebirth.

The decision to give birth at home results in a sequence of events that a woman has to cope with during her preparations for labour and labour itself. The sense of self-efficacy is a psychological feature that facilitates a consistent pursuit of the decision about homebirth that involves the use of one's own strength and resources: educating oneself about labour and labour at home, seeking to hire a midwife specialising in homebirth, skilful manipulation of the information about the decision in different social environments, preparations of the house for the birth, etc, at the same time allowing for seeking and skilful use of external resources such as securing the potentially needed transport to a hospital and organising care for children during labour.

Dispositional optimism facilitates success in managing the tasks related to homebirth and it increases resilience to stress. A woman who decides to give birth at home must not only choose the place to give birth, but also how she will give birth. This is because at home a large part of the responsibility for the success of the natural birth lies with the parents. One of the premises of homebirth is that the woman has full autonomy and control during labour.

Homebirth is more popular among wealthy women, which probably results from the fact that in Poland its costs are not refunded. It is often a decision of women who already have more than one child, frequently more than two. It is an interesting observation that women in the experimental group more often belonged to religious communities than those in the control group.

\section{CONCLUSIONS}

1. It is necessary to see and meet the differing needs of the two different groups of women. The first group comprises women with low-risk pregnancies who decide to give birth at a hospital as this is where they feel safe, and women with high-risk pregnancies who due to the condition of their (or their child's) health must be hospitalized. The second group comprises women with low-risk pregnancies who expect a natural birth and feel safest at home, far from medicalization and hospital procedures.

2. Planned home birth is a social, psychological and medical phenomenon. As such, it requires systematic and reliable interdisciplinary scientific research. It is important for the obstetric care system to be ready for current social changes and processes, including de-medicalization of labour and non-institutional labour (home, birth centres).

3. Scientific research and the evaluation of the practice of home birth would increase the safety of home birth. It is necessary to systematically collect socio-demographic information about women giving birth at home, as well as to pay attention to the statistics gathered by Stowarzyszenie Dobrze Urodzeni (the Society of Well-Born).

4. We suggest further research into the relationships between the choice to give birth at home and the analysed psychological and socio-demographic features. We also suggest the use of the results from the current article in prenatal prognostic tests, which would facilitate the proper selection of women for homebirth.

\section{ENDNOTES}

1 Hosted on the http://moje-ankiety.pl/

\section{References}

Abel, S., \& Kearns, R. A. (1991). Birth Places: A Geographical Perspective on Planned Home Birth in New Zeland. Social Science and Medicine, 33, 825834.

Beebe, K. R., Lee K. A., Carrieri-Kohlman, V., \& Humphreys, J. (2007). The Effects of Childbirth Self-Efficacy and Anxiety During Pregnancy on Prehospitalization Labor. Journal Obstetrics Gynecology \& Neonatal Nursing, 36, 410-418.

Bebelska, K. P., \& Chazan, B. (2011). Korzyści i ryzyko porodu w domu [The benefits and risks associated with homebirth]. In: M. Z. Stepulak, A. Irzmańska-Hudziak, J. Płońska (eds.). Dlaczego rodzić $w$ domu? [Why give birth at home?] (pp. 59-69). Lublin: Wydawnictwo KUL.

Boucher, D., Bennett, C., McFarlin, B., \& Freeze, R. (2009). Staying Home to Give Birth: Why Woman in the United States Choose Home Birth. Midwifery Womans Health, 54, 119-126.
The decision to give birth at home 
Urszula Domańska, Roman Ossowski, Barbara Ciżkowicz
Budrowska, B. (2000). Macierzyństwo jako punkt zwrotny w życiu kobiety [Motherhood as a turning point in a woman's life]. Wrocław: Wydawnictwo Funna.

Callister, L. C., Khalaf, I., Semenic, S., Kartchner, R., \& Vehvilainen-Julkunen, K. (2003). The Pain of Childbirth: Perceptions of Culturally Diverse Women. Pain Management Nurse, 4, 145-154.

Callister, L. C., Vehvilainen-Julkunen, K., \& Lauri, S. (2001). Giving Birth. Perceptions of Finnish Childbearing Women. American Journal of Maternal/ Child Nursing, 26, 28-32.

Carver, Ch. S., \& Gaines, J. G. (1987). Optimism, Pessimism, and Postpartum Depression. Cognitive Therapy and Research, 11, 449-462.

Chołuj, I. (2008). Urodzić razem i naturalnie [To give birth together and naturally]. Mszczonów: Fundacja Źródło Życia.

Christiaens, W., \& Bracke, P. (2007). Assessment of social psychological determinants of satisfaction with childbirth in a cross national perspective. BMC Pregnancy and Childbirth, 7, 26.

Dahlen, H. G., Barclay, L. M., \& Homer, C. (2008). Preparing for the First Birth: Mothers' Experiences at Home and in Hospital in Australia. Journal Perinatal Education, 17, 21-32.

de Jonge, A., van der Goes, B., Ravelli, A., Amelink-Verburg, M., Mol, B., Nijhuis, J., Bennebroek Gravenhorst J., \& Buitendijk, S. (2009). Perinatal Mortality and Morbidity in a Nationwide Cohort of 529 688 Low-Risk Planned Home and Hospital Births. International Journal of Obstetrics and Gynaecology, 116, 1177-1184.

Dilks, F. M., \& Beal, J. A. (1997). Role of Self-Efficacy in Birth Choice. Journal Perinatal Neonatal Nursing, 11, 1-9.

Domańska, U. (2012). Narodziny i system opieki położniczej w kulturze lęku [Birth and the obstetric care system in the culture of anxiety]. In M. Gałuszka, \& M. Wieczorkowska (eds.), Spoteczne, kulturowe i polityczne uwarunkowania ryzyka zdrowotnego [Social, cultural and political determinants of health risk] (pp. 156-175). Łódź: Wydawnictwo Uniwersytetu Medycznego w Łodzi.

Dzierżak-Postek, E., Grzybowska, K., Krauze, M., Oleś, K., Romanowska, M., \&Witkiewicz, M. (2010). Model opieki nad kobietą i dzieckiem w fizjologicznym okresie okołoporodowym w praktyce pozaszpitalnej [The model of care over a woman and child in the physiological perinatal period in the non-hospital practice]. Położna. Nauka i Praktyka, 4, 8-19.

European Court of Human Rights, ECHR 2011/6 Case of Ternovszky v. Hungary, 14 December 2010, no. 67545/09 (Second Section). Retreived from: http://hudoc.echr.coe.int/sites/eng/pages/search. aspx?i=001-102254\#\{“itemid":[“001-102254”]\} [26.08.2014]
Green, J. N. (1993). Expectations and Experiences of Pain in Labor: Findings from a Large Prospective Study. Birth, 20, 65-72.

Hildingsson, I., Radestad, I., \& Lindgren, H. (2010). Birth Preferences that Deviate from the Norm in Sweden: Planned Home Birth versus Planned Cesaren Section. Birth, 37, 288-295.

Janiuk, E. (2011). Domowe narodziny - odpowiedzią na potrzeby rodziny [Homebirth - an answer to family needs]. In: M. Z. Stepulak, A. IrzmańskaHudziak, \& J. Płońska (eds.), Dlaczego rodzić $w$ domu? [Why give birth at home?] (pp. 148-152). Lublin: Wydawnictwo KUL.

Janiuk, E., \& Lichtenberg-Kokoszka, E. (2010). Domowe narodziny. Fanaberia szaleńców czy powrót do normalności? [Homebirth. A mad whim or return to normality?]. Kraków: Wydawnictwo Impuls.

Jouhki, R. (2011). Choosing Homebirth - The Womens Perspective. Women Birth, 14.

Juczyński, Z. (2001). Narzędzia pomiaru w promocji i psychologii zdrowia [Measurement tools in promotion and psychology of health]. Warszawa: Pracownia Testów Psychologicznych Polskiego Towarzystwa Psychologicznego.

Juczyński, Z. (1998). Poczucie własnej skuteczności jako wyznacznik zachowań zdrowotnych [Sense of self-efficacy as an indicator of health behaviours]. Promocja Zdrowia. Nauki Spoteczne i Medycyna, 14, 54-63.

Juczyński, Z. (2000). Poczucie własnej skuteczności - teoria i pomiar [Sense of self-efficacy - theory and measurement]. Acta Universitatis Lodziensis. Folia Psychologica, 4, 11-24.

Kitzinger, S. (1995). Rodzić w domu [To give birth at home]. Warszawa: Państwowe Wydawnictwo Naukowe.

Kornas-Biela, D. (2011). Psychologiczny kontekst rodzenia $w$ domu [The psychological context of giving birth at home]. In: M. Z. Stepulak, A. Irzmańska-Hudziak, \& J. Płońska (eds.), Dlaczego rodzić w domu? [Why give birth at home?] (pp. 178-181). Lublin: Wydawnictwo KUL.

Krauze, M. (2012). Bezpieczeństwo porodów domowych w statystyce [The statistics of safety of homebirth]. Rynek Zdrowia, 18.10.2012, http://www.rynekzdrowia.pl/Moim-zdaniem/ Bezpieczenstwo-porodow-domowych-w-statystyce,124385.html (10.12.2012).

Kubicka-Kraszyńska, U., Otffinowska, A., \& Pietrusiewicz, J. (eds.). (2006). O bólu porodowym i metodach jego tagodzenia [About the labour pain and the methods of its alleviation]. Warszawa: Fundacja Rodzić po Ludzku.

Lally, J. E., Murtagh, M. J., Macphail, S., \& Thomson, R. (2008). More in Hope than Expectation: a Systematic Review of Women`s Expectations and Experience of Pain Relief in Labor. BMC Medicine, 14, 6-7. 
Leap, N., Sandall, J., Buckland, S., \& Huber, U. (2010). Journey to Confidence: Women's Experiences of Pain in Labor and Relational Continuity of Care. Journal of Midwifery Womens Health, 55, 234-242.

Lindgren, H., \& Erlandsson, K. (2010). Women's Experiences of Empwerment in a Planned Home Birth: A Swedish Population-based Study. Birth, 37, 307-319.

Lindgren, H. E., Hildingsson, I. M., Christensson, K., \& Radestad, I. J. (2008). Transfers in Planned Home Births related to Midwife Availability and Continuity: a Nationwide Population-Based Study. Birth, 35, 9-15.

Lobel, M., de Vincent, C. J., Kaminer, A., \& Meyer, B. A. (2000). The Impact of Prenatal Maternal Stress and Optimistic Disposition on Birth Outcomes in Medically High-Risk Women. Health Psychology, 19, 544-553.

Lothian, J. A. (2010). How Do Women Who Plan Home Birth Prepare for Childbirth? Journal Perinatal Education, 19, 62-67.

Lowe, N. K. (1991). Maternal Confidence in Coping with Labor: A Self-Efficacy Concept. Journal of Obstetrical and Gynecological Neonatal Nursing, 20, 457-463.

Lowe, N. K. (1996). The Pain and Discomfort of Labor and Birth. Journal of Obstetetric Gynecologic Neonatal Nursing, 25, 82-92.

Lowe, N. K. (2000). Self-Efficacy for Labor and Childbirth Fears in Nulliparous Pregnant Women. Journal of Psychosomatic Obstetrics \& Gynekology, 4, 219-224.

Manning, M. M., \& Wright, T. L. (1983). Self-Efficacy Expectancies, Outcome Expectancies, and the Persistence of Pain Control in Childbirth. Journal of Personality \& Social Psychology, 45, 421-431.

McDorman, M. F., Declerq, E., \& Menacker, F. (2011). Trend and Characteristc of Home Births in the United States by Race and Ethnicity, 1990-2006. Birth, 38, 17-23.

McDorman, M. F., Declerq, E., \& Mathews, T. J. (2011). United States Home Birth Increase. Birth, 38, 185-190.

Pawlicka, P., Chrzan-Dętkoś, M., \& Lutkiewicz K. (2013). Prężność psychiczna przyszłych matek oraz kolejność ciąży jako moderatory budowania więzi z nienarodzonym jeszcze dzieckiem [Mental resilience of future mothers and the number of pregnancy as moderators of building a bond with an unborn child]. Family Forum, 3, 139-152.

Ponte, W. (2007). Cesarean Birth in a Culture of Fear. Mothering, 9-10, 49-63.

Poprawa, R. (1996). Zasoby osobiste w radzeniu sobie ze stresem [Personal resources in coping with stress]. In: G. Dolińska-Zygmunt (ed.), Elementy Psychologi Zdrowia [Elements of Health Psychol- ogy] (pp. 101-136). Wrocław: Wydawnictwo Uniwersytetu Wrocławskiego.

Rieger, K., \& Dempsey, R. (2006). Performing Birth in a Culture of Fear: An Embodied Crisis of Late Modernity. Health Sociology Review: Journal of the Health Section of the Australian Sociological Association, 15, 364-373.

Sagov, S. E., Feinbloom, R. I., Spindel, P., \& Brodsky, A. (eds.). (1984). Home Birth: a Practitioners Guide to Birth Outside the Hospital. Rockville: Aspen Publishers.

Scheier, M. F., \& Carver, C. S. (1985). Optimism, coping, and health: Assessment and implications of generalized outcome expectancies. Health Psychology, 4, 219-247.

Scheier, M. F., \& Carver, C. S. (1992). Effects of optimism on psychological and physical well-being: Theoretical overview and empirical update. Cognitive Therapy and Research, 16, 201-228.

Viisainen, K. (2000). The moral dangers of home birth: parents' perceptions of risks in home birth in Finland. Sociology of Health \& Illness, 22, 792-814.

Viisainen, K. (2001). Negotiating Control and Meaning: Home Birth as a Self-Constructed Choice in Finland. Social Science Medicine, 52, 1109-1121.

Wegers, T. A., van der Zee, J., \& Keirse, M. J. (1998). Transfer from Home to Hospital: What is its Effect on the Experience of Childbirth? Birth, 25, 19-24.

Witkiewicz, M. (2011). Znaczenie bólu porodowego [The meaning of labour pain]. Magazyn Pielęgniarki i Potożnej, 1-2, 50-51.
The decision to give birth at home 